\title{
Globalization and its impact on the political culture of India
}

\author{
Prof VasantiRasam \\ HOD; Dept. of Political Science, Shivaji University, Kolhapur, Maharashtra State, India
}

\begin{abstract}
Societies where diversity is a predominant feature, political culture often serves as an integrative factor encouraging sharing of what can be shared amidst diversity. Political culture, then, is the abridgment of determined patterns of underlying political attitudes and characteristic responses to political concerns that is manifest in particular political order. The existence of the political culture is generally unperceived by those who are part of that order and its origins date back to the very beginnings of the particular people who share it. Political culture is an essentially a political phenomenon. It makes its own demands on the political system, what is "just" or what is "fair" in the political arena - a direct manifestation of political culture - is likely to be different from the definition of what is just/ fair in case of an individual, family or business relationships. Besides, even different political cultures related to a nation, state, community, or a group will define Justice/ fairness in politics differently. Political culture also affects all other questions confronting the political system. Like, the decisions made towards determining people's expectations from government by the way of services, and political culture will be significant amongst them. Still further political systems, in turn, are in some measure the products of the political cultures they serve and must remain in harmony with their political culture if they are to maintain themselves.
\end{abstract}

Thus political culture is one of the primary sources shaping politics. Political culture has been defined as the "particular pattern of orientations to political action" in which each political system is embedded. ${ }^{1}$ A political culture is related to the general culture of a particular society, but is by no means identical with it. As Gabriel Almond says: "Because political orientation involves cognition, intellection, and adaptation to external situations, as well as the standards and values of the general culture, it is a differentiated part of the culture and has certain autonomy. Like all culture, it is so rooted in the cumulative historical experience of particular groups that it has become second nature to those within its embrace. General culture has its direct impact on politics from the outside, as it were. Political culture, that differentiated aspect of the overall culture which is itself a truly political phenomenon, has its direct impact from the inside.

Political cultures and subcultures arise out of very real socio-cultural differences (ethnic, racial, linguistic, and religious) among people over the years, differences that date back to the very beginnings of civilization. Such differences are to be found within what are commonly conceived to be single nationality groups as often as among them. Theoretically speaking earlier studies have demonstrated that modern and postmodern political culture is expressed through three major political culture variations: that may exist side by side or even overlap. They can be labeled individualistic, moralistic, and traditionalistic. The individualistic political culture emphasizes the conception of the democratic order as a marketplace. In its view, government is instituted for strictly utilitarian reasons, to handle those functions demanded by the people it is created to serve. Since the individualistic political culture emphasizes the centrality of private concerns, it places a premium on limiting community intervention - whether governmental or nongovernmental into private activities to the minimum necessary to keep the marketplace in proper working order, encouraging private initiative and widespread access to the marketplace. The moralistic political culture emphasizes conception of the common wealth as the basis for democratic government. Politics, to the moralistic political culture, is considered one of the great activities of man in his search for the good society - a struggle for power, it is true, but also an effort to exercise power for the betterment of the commonwealth. The traditionalistic political culture is rooted in an ambivalent attitude toward the marketplace coupled with a paternalistic and elitist conception of the commonwealth. It reflects an older, pre-commercial attitude that accepts a substantially hierarchical society as part of the ordered nature of things, authorizing and expecting those at the top of the social structure to take a special and dominant role in government. Like its moralistic counterpart, the traditionalistic political culture accepts government as an actor with a positive role in the community, but it tries to limit that role to securing the continued maintenance of the existing social order.

Now against this background, if we have a look at the political culture of India it seems to fall under the traditionalistic political culture which has a moralist touch. Right since the pre-independence period to post independence, we can say that the freedom movement had provided strong foundations for the future political culture within the rich ancient culture and traditions of India. On the background of freedom movement of India, the then leaders, with their own views on evolving India's political system had debated in various forms. We' have had the extremists and moderates on one hand while we also had leaders influenced by leftist ideology as 
also a large section of fundamentalist Hindus who have been supporting the conservatives. Besides, the Gandhian philosophy has also influenced the Indian political culture giving the ancient spiritual and moral touch. Nehru's visit to USSR and influence in his attitude leading to establish a socialist pattern of society has been reflected in the making of the Indian Constitution.

Free India adopted the best of Liberalism and socialism along with Gandhianphilosohly as its basic ideological construct, which evolved as the political culture of India.Dr.Ambedkar's experienced views and efforts towards emancipation of the downtrodden has also been a part of the political culture of India. Indian leaders then, very thoughtfully adopted the welfare approach towards resolving the issues of Indian social fabric. Right since 1947 the Indian political system, through the Five Year Planning under the role of welfare State had taken up responsibility of the welfare of the downtrodden people- specially the backward castes, classes, the grassroots' level rural society along with women and children's overall development. The government made efforts through various sectors like Public distribution system which provided basic food grains to the poor, health facilities through health centre and free medicine, education at a very low price, agriculture related facilities like provision of fertilizers, seeds, insecticides etc; all at very subsidized price. Even the rural and urban middle class problems were also addressed. Various welfarist policies to change the status of the downtrodden like Special Policies for the upliftment of SC, ST, OBC, Adivasis, tribal communities, besides policies for women and child were implemented. Thus India can be placed in the "traditionalistic political culture" as the people accept government as an actor with a positive role in the community, but it tries to limit that role to securing the continued maintenance of the existing social order. With the traditionalistic political culture under which the general public and the politicians conceive of politics as a public activity centered on some notion of the public good and properly devoted to the advancement of the public interest, in India as mentioned above large number of policies for the advancement of the excluded section of the society were attempted.Although research studies have pointed out that the advancement or change in the socio -economic political status of the excluded society has not been achieved to a satisfactory extent. Yet we cannot deny the fact that the efforts of the Government has definitely led to a change in status and attitude of the Indian society through its political culture. The welfare State approach further was extended to the empowerment and development approach towards upliftment of the excluded Indian Society. This continued up to the coming of globalization with the acceptance of the New economic reforms in 1990's which changed the political culture and political ideology of India.

The present wave of what we now know as globalization can be said to have begun in 1944 as World War II moved into its last phase when the nations allied against the Axis came together at Breton Woods, New Hampshire, to try to establish a worldwide postwar economic regime that would control the problems of trade and finance that had led to the Great Depression of 1929 and to World War II. In the series of economic and fiscal measures hammered out at Dumbarton Oaks in the District of Columbia, the foundations were laid for the network of international financial institutions such as the World Bank, the International Monetary Fund (IMF), and the General Agreement on Trade and Tariffs (GATT) now the World Trade Organization, have proved to be remarkably effective in the task that was set for them.Globalisation is the result of some sort of a conspiracy by the developed countries. They are coming together to conspire against the rest of the world and what has been put out in the name of Globalisation is nothing else, but a new recipe for the imperialist domination over the world. But it's not only a conspiracy by the imperialist west. This argument needs to be understood in terms of the internal dynamics of capitalism and capitalist development in whichthere is a tendency towards centralisation and concentration of capital and over a period of time, you will have fewer and fewer capitalists but larger and larger capitalists. Thus the first characteristic, is the demand on sovereign countries to adopt Financial Liberalisation, while the other part of development that is taking place internationally is the high degree of concentration of industrial capital. The development of globalisation has wide-ranging impact on political culture and developments, which particularly go along with the decrease/reduction of the importance and role of the state. Through the creation of sub-state and supra-state institutions such as the EU, the WTO, the G8 or the International Criminal Court, the state loses power of decision/policy making and thereby ultimately loses its sovereignty.

Globalisation was opposed and resisted by communist tradition and the third world countries, as well as the newly liberated nations and the peripheral nations who tried to avoid the impact of Globalization, but in vain. Basically the changes in China right since 1978 and Chinese efforts towards modernization in spheres of Agriculture Industry, military and education along with the acceptance of the new economic model breaking the old traditions on one hand andwith the collapse of socialism in the Soviet Union and Eastern Europe, the economic counter-veiling power that existed globally collapsed. These former socialist economies were also sucked into the vortex of the global capitalism. This vision envisaged the global domination of the West particularly of imperialism under the leadership of United States of America. It was given a concrete and also a legal shape. The institutions of the IMF, the World Bank, and the later-formed WTO in 1994, all these became the instruments to establish and put into practice this new world order. The third world also was entrapped in 
this process of what Talcott Parsons called it as a Linear theory of change. all societies are moving towards in one directions led by US Linear theory and not cyclical theory of change thereby those nations who stood for autonomy, development of public sector- looked forward to resolve their economic problems leading the to ultimately accept new economic policy. In case of India too, which is considered as a leading Third wold nation, 1991 when it faced economic problems like problem of liquidity during Chandrasekhar's Prime Ministership extending uptoNarsimhaRao's Prime Ministership, India accepted the New Economic Policy( NEP).With this acceptance the Third world opposition dissolved and diluted..

The government of India, under severe economic crisis, recovered the structural crisis, received the Structural Adjustment loan from the IMF which are granted with condition relating to structural changes in the Indian economy. As per the expectations, these reforms were to lead to the integration of the Indian economy with the world. Globalization and NEP are closely related to the Market economy through which nations were brought under the domination of Market economy leading to discriminatory relations. In case of India this change in the Indian Political culture towards modernization through the market economy has been leading to a greater gap between have and have-nots, creating discriminatory relations and injustice in the society. But in actuality the reforms led to gradually lessen the governmental control over the market, reduce export subsidies, promotion of free trade, privatize public sectors, etc.

Thereby the first major impact of globalization on the Indian political culture reflects in the decreasing decision /policy making power of India as a sovereign state. The loan received through the Structural Adjustment programme from the IMF are granted with condition relating to structural changes in the Indian economy, but in fact it has led to total change in the political culture of India. Economic globalization spells the end of the welfare state and social democracy. In effect, the hyperglobalists hold, the autonomy and sovereignty of nation-states have been eclipse by contemporary processes of economic globalization. Still further, globalization does not simply denote a shift in the extensity or scale of social relations and activity. The transformationalists more significantly, argue, it also involves the spatial re-organization and re-articulation of economic, political, military and cultural power. (see Held and McGrew, et al, 1999).

The conditions that have come along with the financial aid, have led to decontrol over the market, reduce export subsidies, promotion of free trade, privatize public sectors. Thereby India today has to follow the guidelines that come along with the conditions. The conditions have paralyzed the decision making power of the sovereign state. If we take into consideration the condition of free trade and free flow of finance along with the privatization of public sector of market and with the free flow of foreign goods and foreign finance the domestic production of goods and business have definitely been hampered. The Indian public sector is being closed down and space is made for Indian as well as foreign private sector. The public sector under the socialistic culture was meant to serve the downtrodden in a subsidized form that extended to provision of food grains kerosene, LPG gas, health services, education, housing facility as well as agricultural services. The government has been providing these services to rural as well as urban areas which definitely has made a remarkable change in the status of the downtrodden in the diversified society leading to the development of the society, be it the SC's, ST's, OBC's, EBC's Adivasis, women or children from the social strata of the society. But with globalization the withdrawal of the State from its responsibilities reflects in the reduction of the expenditure on the social sector like the Public distribution system, Health services, Sanitation services,as well as in the agricultural services through which the poor farmers were provided services at a subsidized rate, unfortunately, has led to problem of food security as well as starvation death in cases of poor families in urban as well as rural areas. The quantity of low cost food grain that was available to the BPL families is declining along with the deterioration in quality. The removal of food subsides under liberalization has led to decrease in the amount of food purchase from public distribution system. In the same way it has a very negative impact on the health services where the Government expenditure is declining day by day. The poor are being denied the right to live by reducing the expenditure on health services and Government health centers are in a very bad shape in terms of cleanliness, space, equipment and infrastructure. Besides, the growing cost of medicine under patenting is unaffordable by the poor.

Similarly, agriculture in India being the major sector, large majority of poor farmers have been trapped into the clutches of agricultural policy under Globalization and New Economic policy. It has in fact led to change the face of the successful traditional agricultural face of India, by control over the seeds, fertilizers, pesticides, cropping pattern. This situation has been established by researchers to be one of the major causes of increasing farmer's suicides popularly known as "Debt -Death Trap." The post-global impact on agriculture has led to grave problems of food security not only incase of poor but middle class too. The rights of the small farmers to land, water and biodiversity are being violated by undoing land reforms, by privatization of water, monopolization over seed and plant resources. With the spread of ecologically and destructive farming methods, the ecological rights of our farmers have been denied. The land reforms which had a ceiling in land holding are being undone in various states to allow corporate farming and super farming for luxury production. Food growing land is being diverted to non-food crops or luxury farming like flowers, shrimp etc. Corporate farming / 
agriculture on the other hand is leading to neo-poverty states of small farmers as unfair and unequal contracts are making them neo-bonded laborers. The privatization wave has led to the closure of public sectors. The consequences are being faced by the poor \& labour section of the industry leading to unemployment and increase in poverty

As globalization gained momentum, market substituted political ideology as the dominant force guiding national and global policies. What followed next, therefore, does not seem so illogical. National governments everywhere - partly in deference to the ascendancy of the market and partly in response to pressure from the private sector to expand their sphere of activities - began to relinquish control over the delivery of social goods. Everything began to be viewed as a commodity that could be produced and delivered by the private sector in line with market forces and according to the principles of supply and demand. One by one water, electricity, postal services, health, and now education, have been turned into a commodity. We have discussed the impact of globalization on Public distribution system, Health services, and agriculture in brief, just to point out the multi-tentacle impact on the political culture of India. Education sector has been chosen as one of the major social sector could be discussed in detail to understand intricate repercussion of globalization, since it is covered under service sector and looked upon as a commodity as it is being experienced by the whole society as such.

In case of education it has always been a continuous and most important needs of mankind. It helps man indoctrinate values and apply the technical know-how in real life situations. Through the GATS, unfortunately education has been covered under the service sector with an idea of establishing a open, global market where services like education can be traded to the highest bidder. GATS includes education as a service sector under Primary, secondary, Higher, Adult and Other education under four modes of supply of education through Cross border supply. The major consequences of the globalization of education have been commoditization and the corporatization of institutions of higher learning. If we compare at global level, about 35\% of world's illiterate population is Indian and, based on historic patterns of literacy growth across the world, India may account for a majority of the world's illiterates by 2020.The public expenditure on education has actually declined from around 3.23 percent of GDP in 2000-2001 to 2.88 percent in the recent times. Taking into consideration the proportion of total government expenditure, it has declined from around 11.1 percent in 2000-2001 to around 9.98 percent during UPA rule. A policy brief issued by Network for Social Accountability (NSA)]titled "NSA Response to Education Sector Interventions in Union Budget: UPA Rule and the Education Sector]" provides significant revelation to this fact. According to United Nations Educational, Scientific and Cultural Organization (UNESCO), India has the lowest public expenditure on higher education per student in the world. Due to a declining priority of education in the public policy paradigm in India, there has been an exponential growth in the private expenditure on education also.

With the increasing trend towards privatization of higher education in India, the Government of India is trying to absolve itself from the responsibility of providing higher education to its citizens. But infact the Government is obliged to not only strive towards providing access to higher education to all its citizens but must also try and improve the quality of higher education in India. In order to cater to these needs, a large investment is required. But in India, lack of adequate funds continues to be a major hurdle. In the given context, we are leading towards privatization and monopolization of higher education by the Private Sector. 'Privatization' raises several issues like; would it be feasible to have a Public- Private partnership as far higher education is concerned? Would the disadvantages of Privatization outweigh its advantages? Would Privatization in India lead to monopolization of Higher Education by the Private Sector? These are some of the compelling questions that crop up in the era of globalization and privatization. As per the available information, the private out of pocket expenditure by the working class population for the education of their children in India has increased by around 1150 percent or around 12.5 times over the last decadeand transnational education has become a possibility. Multi campus institutions, "franchised institutions learning centers providing universities are coming up, while on the other hand under globalization innovative forms of translocation degree, off campus education, distance learning, internet based distance education, virtual universities, merging of part studies to combine into a whole for obtaining national as well as international degrees are only few models. As far as higher education is concerned, a well-informed student has umpteen choices, for the first time in the history of education, to access for a "global marketplace". Yet, the matter of the fact is, this access remains only as availability. How many and who can reach to it and how? What alternative provisions are made for those who cannot afford to reach, is the crux of the matter, has become a million dollar question today.

To finance the above mentioned expansion, the Government of India has consistently increased its share in the total expenditure on Higher Education-from 49.1 percent in 1950-51 to more than 90 percent today. It is significant that despite these impressive statistics the system caters to hardly 6 percent of the relevant age group, as compared to more than 80 per-cents in the developed countries. The fact illustrates how difficult it is for developing countries to bridge gaps and to keep pace with the developed world. Resource constraints are severe, and the quality of education available to most Indian students is questionable in terms of its ability to face the 
challenges posed by further education as well as employment market. The situation is further complicated by the rigidities of the higher education system, the political pressures from regional, religious and other such groups, and related problems. Thus, when we get to know about the implication of Globalizations on developing countries, irrespective of the kind political System, it has caused much damage rather than improving the condition of the developing countries.

India is one of the largest higher education system in the world facing the crisis of Government funded university of the poor, with continued expansion, deteriorating standards, limited resources, and political involvement . In this regard, it is important to note that recently, the Indian government has approved the Foreign Education Providers (Regulatory) Bill (2010) that will allow foreign universities to open branches in India. When this bill becomes a law after approval in the parliament, foreign universities will be able to enter the education market. However, this raises some concerns among Indian politicians as many believe that there would be no control, over export and import of higher education, and the private institutions, from overseas would open branches in India, exchange of degrees and certificates that would go on without any restrictions. Some of politicians argue that Indian Universities are already at loss as more than 50,000 students of our country are studying abroad in U.S., Australia and U.K., where as a very small number of foreign students are seeking admissions in Indian Universities. There is a serious imbalance between educational need and educational capacity of many of our universities. To add, the experience of the higher education which, under the aegis of privatization the institutions have been largely established in metropolitan cities. Only the rich who can afford (i.e. with economic capability) are able to avail such higher education. It is not only leading to a divide between have and have-nots, but it has been destabilizing and distorting the indigenous culture, tradition and values.

Overall, although through this paper only the education sector has been elaborately dealt with in high lighting the impact of globalization on the political culture of India,statistical data is available to prove the same situation in Public distribution system, health, water, sanitation, and most importantly on the culture of agriculture which was and is considered to be the backbone of the Indian economy along with the Public industry, which as of today greatly relies on the intervention of the political system and government as such. While today in the context of the political dimensions of the G.L.P. the sovereignty of India, as a State is at stake with its diminishing decision making power. But there is a need to protect the constitutional provisions with regard to access, equity and equality. The percentage of the beneficiaries of this privatization is very small, while a large percentage is at disadvantage. To convert the threats into opportunities, there is a need of either restructuring the political system accommodating the welfarist approach and Indian political culture., while we accept the need to primarily go for nationalization prior to globalization, besides equalization provision of access and opportunities and decentralize powers to the stake holders. The 'political will' required is missing due to which strong civil society movement and uprisings are growing fast in India to main the political culture in India along with the positive implications of Globalization.

\section{References}

[1]. Gabriel Almond, Comparative Political Systems," Journal of Politics 18 (August 1956): 396. See also Lucian W. Pye and Sidney Verba, eds., Political Cultural and Political Development (Princeton, NJ: Princeton University Press, 1965);

[2]. Donald J. Devine, The Political Culture of the United States (Boston: Little Brown, 1972);

[3]. Raymond D. Gastil, Cultural Regions of the United States, (Seattle: University of Washington Press, 1975);

[4]. Aaron Wildavsky, Cultural Theory (Boulder, CO: Westview Press, 1990);

[5]. Edward K. Hamilton, ed., America's Global Interests: A New Agenda (New York: W. W. Norton, 1989).

[6]. Lucien Pye, "Culture and Political Science: Problems in the Evaluation of the Concept of Political Culture," Social Science Quarterly 53 (September 1972):

[7]. Lucien Pye and Sidney Verba, eds., Political Culture and Political Development (Princeton: Princeton University Press, 1965);

[8]. Gabriel Almond and Sidney Verba, The Civic Culture (Boston: Little Brown, 1963).

[9]. Daniel J. Elazar, American Federalism: A View From the States (T.Y. Crowell, 1966).

[10]. Sainath, P 2004 'Seeds of suicide', The Hindu, July 20, 2004.

[11]. Sainath, P 2005 'As you sow, so shall you weep' The Hindu, May 30, 2005.

[12]. Sainath, P 2005, 'Spice of life carries whiff of death', The Hindu, February ,13,2005.

[13]. Sainath, P 2004 'Dreaming of water, drowning in debt', The Hindu, July 18, 2004.

[14]. 'Seeds of ruin', The Indian Express, July 3, 2005.

[15]. 'The damage done: aid, death and dogma', May 2005, ChristianAid.christianaid.org.uk/indepth/505caweek/CAW\%20report.pdf

[16]. Whose suicide is it anyway', Indian Express, June 23, 2005

[17]. Sainath ,P -2010" FOOD FOR ALL" -Food security - of APL, BPL and IPL -India together ;- 10 July 2010

[18]. Shiva Vandana, Voluntary Services Overseas (VSO) 26,Aug.1997

[19]. Shiva Vandana, Conference proceedings -New Delhi 2010

[20]. Food Sovereignty: A Right For All, Political Statement of the NGO/CSO Forum for Food Sovereignty. Rome, June 2002; http://www.grain.org/seedling/?id

[21]. India 2009: A Reference Annual (53rd edition), New Delhi: Additional Director General (ADG), Publications Division, Ministry of Information and Broadcasting, Government of India, ISBN 978-81-230-1557-6.

[22]. "Higher Education", National Informatics Centre, Government of India". Education.nic.in. Retrieved 2010-09-01.

[23]. Blackwell, Fritz (2004), India: A Global Studies Handbook, United States of America: ABC-CLIO, Inc., ISBN 1-57607-348-3. 
[24]. Siba Shankar Mohanty-Response to Education Sector Interventions in Union Budget-UPA Rule and the Education Sector.

[25]. How the Working Class has Performed in the Turbulent Years of Liberalisation-A Priliminary Study of Working Class Income and Expenditure Survey1999-2000 Page-1". Nsa.org.in. Retrieved 2010-09-01.

[26]. Singh M.K. -Challenges of Globalization in Higher Education

[27]. The Impacts of Globalization in Higher Education Navin Singh, Rosemary Papa) 